\title{
Seasonal and diurnal variability of essential oil and its components in Origanum onites L. grown in the ecological conditions of Çukurova
}

\author{
By Gülsüm Yaldiz ${ }^{1}$ Nazim Şekeroglu ${ }^{2 \star}$ Menșure Özgüven ${ }^{1}$ Muzaffer Kirpik ${ }^{1}$
}

\author{
${ }^{1}$ Çukurova University Agricultural Faculty Field Crops Department, 01330 Adana - Turkey. \\ ${ }^{2}$ Karadeniz Technical University Ordu Agricultural Faculty Field Crops Department, \\ 52200 Ordu - Turkey. Phone: +90 4522300556-57, Fax: +90 4522251261, E-mail: nazim@ktu.edu.tr
}

\section{RESUMEN}

Variabilidad estacional y diurna del aceite esencial de Origanum onites $\mathrm{L}$. cultivado en las condiciones ecológicas de Çukurova.

El orégano turco (Origanum onites L.) es uno de los más recolectados de la naturaleza así como la especie de orégano más cultivada en Turquía. Además es la especie de orégano más exportada desde Turquía a todo el mundo.

En este trabajo se estudió la variabilidad estacional y diurna del contenido de aceite esencial de Origanum onites L. cultivado en las condiciones ecológicas de Çukurova desde Septiembre de 2000 a Agosto de 2001 . Se estudió también la variabilidad mensual de la composición del aceite esencial.

Los plantones recogidos en la región fueron plantados en un invernadero y transferidos al campo en un diseño con tres replicados. Un año después del transplante, se recogieron hojas verdes de la parte superior de las nuevas plantas los lunes de cada semana tres veces al día $\left(08 .^{00}, 12 .^{00}\right.$ y $16 .^{00}$ horas) durante el año. El contenido y la composición del aceite esencial fueron analizados en muestras de las hojas frescas obtenidas mediante hidrodestilación.

El contenido de aceite esencial cambió de acuerdo con las estaciones y la hora del día. El contenido más alto $(1,92 \%)$ se encontró en la post floración, al principio del periodo de formación de la semilla, en las recolecciones de la tarde durante la segunda mitad de Junio (semana $n^{\circ} 40$ ). La composición del aceite esencial varió mensualmente y el valor más alto $(73,65 \%)$ de carva$\mathrm{crol}$, el principal componente del aceite esencial, se obtuvo en el periodo de floración en Mayo.

PALABRAS-CLAVE: Aceite esencial - Orégano turco - Origanum onites $L$. - Variabilidad estacional y diurna.

\section{SUMMARY}

Seasonal and diurnal variability of essential oil and its components in Origanum onites L. grown in the ecological conditions of Çukurova.

Turkish Oregano (Origanum onites L.) is one of the most commonly collected from nature as well as cultivated Origanum species in Turkey. In addition, Turkish Oregano is the most exported Origanum species from Turkey to the entire World.

In this study, the seasonal and diurnal variability of the essential oil content in Origanum onites L. grown in the ecological conditions of Çukurova was studied from September 2000-August 2001. Monthly variability of the essential oil composition was also studied.

The plant cuttings collected from the region were rooted in the greenhouse and transferred to the field in a split plot design with three replications. One year later from transplanting,fresh leaves from the top shoots were collected every week three times a day on Monday (at $08 .^{00}, 12 .^{.0}$ and $16 .{ }^{.0}$ o'clock) throughout the year.
The content and composition of the essential oil were analysed in fresh leaf samples by hydrodistillation.

The essential oil content changed according to the seasons and the hour of day. The highest essential oil content (\% 1.92) was found in the post-flowering -at the beginning of the seed formation period in the afternoon harvests during the second half of June ( $40^{\text {th }}$ week). The essential oil composition varied monthly and the highest value (\% 73.65) of carvacrol, the main component of the essential oil, was obtained from the flowering period in May.

KEY-WORDS: Essential Oil - Origanum onites L. - Seasonal and Diurnal Variability - Turkish oregano.

\section{INTRODUCTION}

Turkish Oregano (Origanum onites L.) is widely used as a spice and herbal tea in Turkey. The essential oil and hydrosols of Turkish Oregano is consumed as traditional medicine for treating gastrointestinal disorders and diabetes. This species is one of the most collected from nature as well as cultivated Origanum species especially in the Aegean region of Turkey. Turkish Oregano is the most exported Origanum species from Turkey to the entire World.

Origanum onites $\mathrm{L}$. is locally distributed in Turkey, Greece and Sicily (Italy) (Kokkini, 1996). This Origanum species has been naturalized in Balikesir, Marmara Island, Manisa, Aydin, Muğla, Fethiye, Denizli, Antalya, Isparta and Beysehir districts of Turkey (Davis, 1982). Turkish Oregano is characterized mainly by its umbrella-shaped flowers which are rich in essential oil and flowering continues from April to August. In the essential oil plants, the content of the essential oil is affected by the part of the plant, growing stages, time of day, climate, environment, plant age and genetic structure (Ceylan, 1995; Demir, 1974).

The essential oil content and its composition are one of the most important quality criteria for Oregano in all purposes. Dried Oregano leaves must have at least $2.0-4.5 \%$ essential oil content for market demands. Because of its powerful antimicrobial properties, carvacrol, the main component, content of the essential oil is considered as a quality criterion (Tepe et al., 2004).

The objective of the present study was to determine the effect of harvest time on the essential 
oil content and its components of Turkish Oregano grown in the ecological conditions of Çukurova.

\section{MATERIALS AND METHODS}

Origanum onites $L$. has naturally been found in the Cukurova region, which has a wide range of aromatic plant genetic resources and is located along the east coast of the Mediterranean region. Oregano cuttings used in this study were collected from the natural flora. The plant cuttings were rooted in the greenhouse and transferred to the field conditions. The rooted cuttings were planted in spaces of $30 \times 30 \mathrm{~cm}$ in a split plot design with three replications. The main plots were allotted to the weeks and the subplots to the sampling hours in a day. The leaf samples were taken three times (at $08 .^{00}, 12 .^{.0}$ and $16 .^{00}$ o'clock) on every Monday for 48 weeks throughout the research year, three replicates in each sampling.

This study was carried out in the ecological conditions of Çukurova from September 2000-August 2001. In this region, for the research year, the average climatic values are given in Table 1 . The soil characteristics of the region were sandy-loam and light alkaline $\left(\mathrm{pH}\right.$ : 7.29). The nitrogen, $\mathrm{P}_{2} \mathrm{O}_{5}$ and lime contents in the experimental area were $0.112 \%, 141.7$ $\mathrm{kg} / \mathrm{ha}$ and $33.02 \%$, respectively.

The samples were taken after one year of transplanting. The plant sampling started in September, 2000 and continued throughout the year. The fresh plant materials were harvested from the top of the plants.

For determining the essential oil content, samples $(20 \mathrm{~g})$ were submitted to hydrodistillation for 2 hours using a Clevenger-type apparatus with three replicates.

For identification of the essential oil components, Gas Chromatograph (Hewlett Packard Model 6890) was performed in a split/splitless injection system equipped with a FID and a DB-5 capillary column $(30 \mathrm{~m} \times 0.25 \mathrm{~mm}$ i.d.; $0.25 \mu \mathrm{m}$ film thickness). Temperature was programmed from $50{ }^{\circ} \mathrm{C}$ at $5 \mathrm{~min}$ then programmed at $4^{\circ} \mathrm{C} / \mathrm{min}$ to $260^{\circ} \mathrm{C}$. The carrier gas was nitrogen. The essential oil components: $\alpha$-pinen, $\beta$-pinen, $\alpha$-terpinen, 1,4-cineol, $\gamma$-terpinen, linalool, borneol, thymol and carvacrol were identified by comparing linear retention indexes with those from authentic compounds.

The statistical analyses were done according to split plot design by computer statistical program, MSTATC. The differences among the means were compared using LSD (5\%).

\section{RESULTS AND DISCUSSION}

In this study, the essential oil content of Turkish oregano varied from $0.23-1.92 \%$ according to the time of day and week of the year (Table 1). The highest essential oil content (\% 1.92) was obtained from the $40^{\text {th }}$ week, at the end of flowering-beginning of seed formation period, the second half of June. The essential oil content increased as the plant grew but it began to decrease significantly after the seed-set period. The lowest value $\left(\begin{array}{ll}0.23\end{array}\right)$ was obtained during the $21^{\text {st }}$ week, the first week of February (Figure 1).

Although the essential oil content began to increase with plant growth, a slight decrease occurred in May. This may be due to unusual weather conditions, more rainfall and lower temperatures than those throughout the year in the region.

The essential oil content of Turkish Oregano changed according to the month and the time of day (Figure 1). Essential oil contents from morning samplings were higher in October, November and July, but the afternoon samplings produced higher values in September, February and May. Although the noon samplings produced higher values in June, there were no statistical differences between the noon and afternoon samplings in April and August. The three sampling hours had no significant effect on the essential oil content in December, January and March.

In the scientific literature, several papers are available indicating that the essential oil content of the Origanum species reaches its highest values at full blooming stage and at the beginning of seed formation (Ceylan, 1995; Özgüven and Stahl-Biskup, 1989; Özgüven et al., 1996; Bayram, 1995; Kokkini, 1996).

The essential oil contents obtained in the present study were lower than those of other researchers in the literature. In our study, fresh plant material was used for the essential oil analysis. Since fresh plant material contains higher water content than dried materials, their essential oil content is expected to be lower, as in the present study.

The mean values of the essential oil content for the sampling hours are given in Table 2 . Taking into

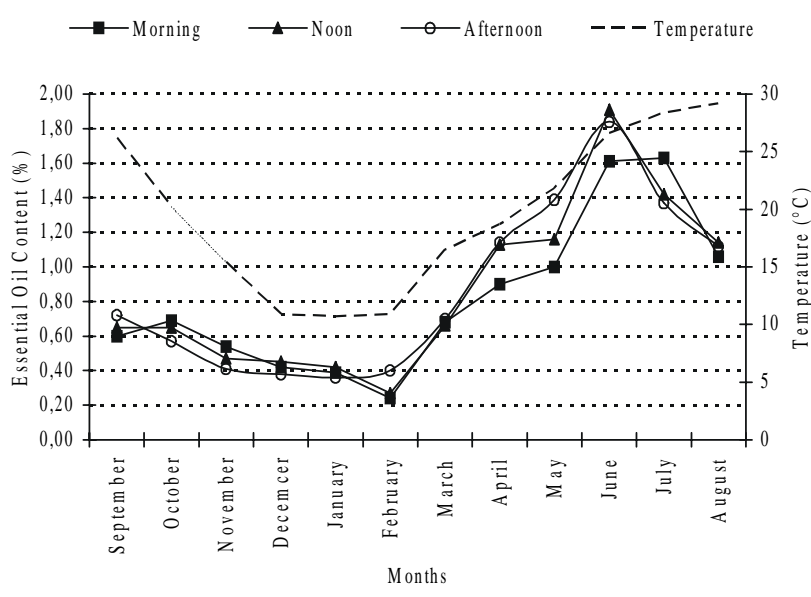

Figure 1

Variation of the essential oil contents of Turkish oregano within daytime and months. 
Table 1

Average climatic values and essential oil contents of Turkish oregano throughout the year

\begin{tabular}{|c|c|c|c|c|c|}
\hline Seasons & Months & Weeks in Year & Essential Oil Content (\%) & Temp. $\left({ }^{\circ} \mathrm{C}\right)$ & Rainfall (mm) \\
\hline \multirow{12}{*}{ 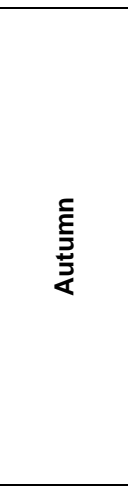 } & \multirow{4}{*}{ September, 2000} & 1 & $0.68 \mathrm{kl}$ & \multirow{4}{*}{26.2} & \multirow{4}{*}{41.2} \\
\hline & & 2 & $0.68 \mathrm{kl}$ & & \\
\hline & & 3 & $0.62 \mathrm{klmn}$ & & \\
\hline & & 4 & $0.64 \mathrm{klmn}$ & & \\
\hline & \multirow{4}{*}{ October, 2000} & 5 & $0.83 \mathbf{i} \mathbf{j}$ & \multirow{4}{*}{20.2} & \multirow{4}{*}{135.7} \\
\hline & & 6 & $0.66 \mathrm{klmn}$ & & \\
\hline & & 7 & 0.54 mnop & & \\
\hline & & 8 & 0.53 nop & & \\
\hline & \multirow{4}{*}{ November, 2000} & 9 & $0.48 \mathrm{opq}$ & \multirow{4}{*}{15.4} & \multirow{4}{*}{30.8} \\
\hline & & 10 & 0.49 opq & & \\
\hline & & 11 & $0.47 \mathrm{pq}$ & & \\
\hline & & 12 & $0.44 \mathrm{pq}$ & & \\
\hline \multirow{12}{*}{$\frac{\grave{d}}{\stackrel{ \pm}{5}}$} & \multirow{4}{*}{ December, 2000} & 13 & $0.48 \mathrm{opq}$ & \multirow{4}{*}{10.9} & \multirow{4}{*}{37.7} \\
\hline & & 14 & $0.44 \mathbf{p q}$ & & \\
\hline & & 15 & 0.37 qrs & & \\
\hline & & 16 & 0.37 qrs & & \\
\hline & \multirow{4}{*}{ January, 2001} & 17 & $0.40 \mathrm{qr}$ & \multirow{4}{*}{10.7} & \multirow{4}{*}{8.6} \\
\hline & & 18 & 0.28 rst & & \\
\hline & & 19 & $0.40 \mathrm{qr}$ & & \\
\hline & & 20 & 0.47 opq & & \\
\hline & \multirow{4}{*}{ February, 2001} & 21 & $0.23 \mathrm{t}$ & \multirow{4}{*}{10.9} & \multirow{4}{*}{74.9} \\
\hline & & 22 & $0.26 \mathrm{st}$ & & \\
\hline & & 23 & $0.27 \mathrm{st}$ & & \\
\hline & & 24 & $0.44 \mathrm{pq}$ & & \\
\hline \multirow{12}{*}{$\begin{array}{l}\frac{9}{2} \\
\text { के }\end{array}$} & & 25 & 0.56 Imnop & & \\
\hline & & 26 & $0.59 \mathrm{kImno}$ & & \\
\hline & March, 2001 & 27 & $0.71 \mathbf{j k}$ & 16.5 & 46.6 \\
\hline & & 28 & $0.85 \mathbf{i}$ & & \\
\hline & & 29 & $0.82 \mathbf{i} \mathbf{j}$ & & \\
\hline & & 30 & $1.04 \mathrm{gh}$ & & \\
\hline & April, 2001 & 31 & $1.20 \mathrm{f}$ & 18.7 & 8.8 \\
\hline & & 32 & $1.18 \mathrm{f}$ & & \\
\hline & & 33 & $1.39 \mathrm{de}$ & & \\
\hline & & 34 & 0.92 hi & & \\
\hline & May, 2001 & 35 & $1.06 \mathrm{~g}$ & 21.8 & 130.4 \\
\hline & & 36 & $1.36 \mathrm{de}$ & & \\
\hline & & 37 & $1.63 \mathrm{c}$ & & \\
\hline & & 38 & 1.74 bc & & \\
\hline & June, 2001 & 39 & $1.84 \mathrm{ab}$ & 26.6 & - \\
\hline & & 40 & $1.92 \mathbf{a}$ & & \\
\hline & & 41 & $1.63 \mathrm{c}$ & & \\
\hline $\bar{\Xi}$ & & 42 & $1.33 \mathbf{e}$ & & \\
\hline$\overline{\mathrm{g}}$ & July, 2001 & 43 & $1.48 \mathrm{~d}$ & 28.4 & - \\
\hline & & 44 & $1.43 \mathrm{de}$ & & \\
\hline & & 45 & $1.20 \mathrm{f}$ & & \\
\hline & & 46 & $1.37 \mathrm{de}$ & & \\
\hline & August, 2001 & 47 & $1.14 \mathrm{fg}$ & 29.2 & 31.1 \\
\hline & & 48 & $0.71 \mathbf{j k}$ & & \\
\hline & & Total Rainfal & verage of Temperature Values & $19.6^{\circ} \mathrm{C}$ & $545.8 \mathrm{~mm}$ \\
\hline
\end{tabular}

LSD (5 \%): 0.1256 . There were no statistical differences among the means shown by the same letters

consideration the entire year, the effect of sampling hours (diurnal variability) on essential oil content of
Turkish oregano was statistically significant. The highest values were recorded at noon and in the 
Table 2

Average essential oil content of Turkish oregano during daytime

\begin{tabular}{|c|c}
\hline Sampling Time (O'clock) & Essential Oil Content (\%) \\
\hline $\mathbf{8}$ & $0.81 \mathbf{b}$ \\
\hline $\mathbf{1 2}$ & $0.86 \mathbf{a}$ \\
\hline $\mathbf{1 6}$ & $0.87 \mathbf{a}$ \\
\hline
\end{tabular}

LSD (5\%): 0.03119 . There were no statistical differences among the means shown by the same letters.

Table 3

Average values of essential oil components in Turkish oregano throughout the year

\begin{tabular}{|c|c|c|c|c|c|c|c|c|c|}
\hline Months & 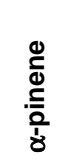 & 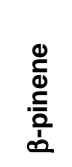 & $\begin{array}{l}\frac{0}{5} \\
\frac{\Phi}{0} \\
\frac{0}{0} \\
\frac{1}{8}\end{array}$ & $\begin{array}{l}\bar{d} \\
\stackrel{\bar{d}}{0} \\
\dot{t} \\
-\end{array}$ & 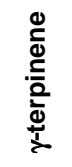 & $\begin{array}{l}\bar{\circ} \\
\frac{\circ}{\pi} \\
\stackrel{.}{J}\end{array}$ & 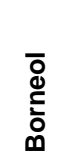 & 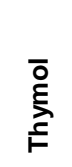 & 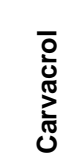 \\
\hline September & Tz & Tz & 15.46 & Tz & 9.31 & 11.65 & $\mathrm{Tz}$ & $\mathrm{Tz}$ & 60.33 \\
\hline October & Tz & Tz & 12.29 & Tz & 9.43 & 12.90 & Tz & Tz & 65.37 \\
\hline November & $\mathrm{Tz}$ & Tz & Tz & 6.37 & 4.18 & 13.78 & 2.67 & Tz & 68.58 \\
\hline December & Tz & Tz & 3.76 & Tz & 3.57 & 17.51 & Tz & 2.10 & 70.18 \\
\hline January & $\mathrm{Tz}$ & Tz & Tz & 3.61 & 2.95 & 16.62 & 2.77 & 2.87 & 63.70 \\
\hline February & $\mathrm{Tz}$ & 0.99 & Tz & 2.68 & 4.35 & 12.64 & 2.30 & 1.92 & 47.41 \\
\hline March & $\mathrm{Tz}$ & 1.19 & Tz & 2.66 & 6.13 & 13.51 & 1.26 & 1.79 & 63.61 \\
\hline April & Tz & 1.72 & Tz & 1.06 & 8.02 & 10.82 & 1.50 & 2.78 & 57.84 \\
\hline May & 1.36 & 1.90 & 1.18 & 7.31 & 5.32 & 3.93 & 1.60 & 1.33 & 73.65 \\
\hline June & 1.18 & 1.97 & 1.26 & 1.22 & 6.95 & 6.81 & 2.00 & 2.97 & 62.37 \\
\hline July & Tz & Tz & Tz & 5.26 & 3.71 & 2.44 & 2.14 & Tz & 62.21 \\
\hline August & $\mathrm{Tz}$ & Tz & 18.63 & Tz & 9.18 & 10.39 & Tz & Tz & 55.29 \\
\hline Mean & 0.21 & 0.65 & 4.38 & 2.51 & 6.09 & 11.08 & 1.35 & 1.31 & 62.55 \\
\hline
\end{tabular}

Tz: Trace levels

afternoon samplings. It has been reported that in the essential oil plants, the content of the essential oil is varied throughout the day and generally the essential oil contents increase from the morning to the afternoon and then decrease into the night (Ceylan, 1995; Binokay and Özgüven, 1987).

The composition of the essential oil and amounts of its components in Turkish Oregano sampled throughout the year varied with plant growing stages. As the $\gamma$-terpinene, linalool and carvacrol in the essential oil were detected in all the samplings, some components did not exist in the analysis of essential oil of the samples taken in some months (Table 3).

The average values of carvacrol, linalool, $\gamma$-terpinene, $\alpha$-terpinene, 1,4-cineol, borneol, thymol, $\beta$-pinene and $\alpha$-pinene changed from 47.41-73.65
$\%, \quad 2.44-16.62 \%, \quad 2.95-9.40 \%, \quad 1.18-18.63 \%$, $1.06-7.31 \%, 1.26-2.77 \%, 1.33-2.97 \%, 0.99-1.97 \%$ and $1.18-1.36 \%$, respectively.

Carvacrol, the main component in the essential oil of Turkish Oregano, had the highest value (73.65 $\%)$ in May when the oregano plants were in their full blooming stage. All the essential oil components of Turkish Oregano were found in May and June. These findings may indicate that when the essential oil content reaches its highest value, the number and amount of essential oil components are at a maximum (Figure 2).

Otan et al. (1994) and Kokkini (1996) stated that, the season of collecting may strongly affect the essential oil yield of the plants and the concentration of its main components. Biondi et al. (1993) and 


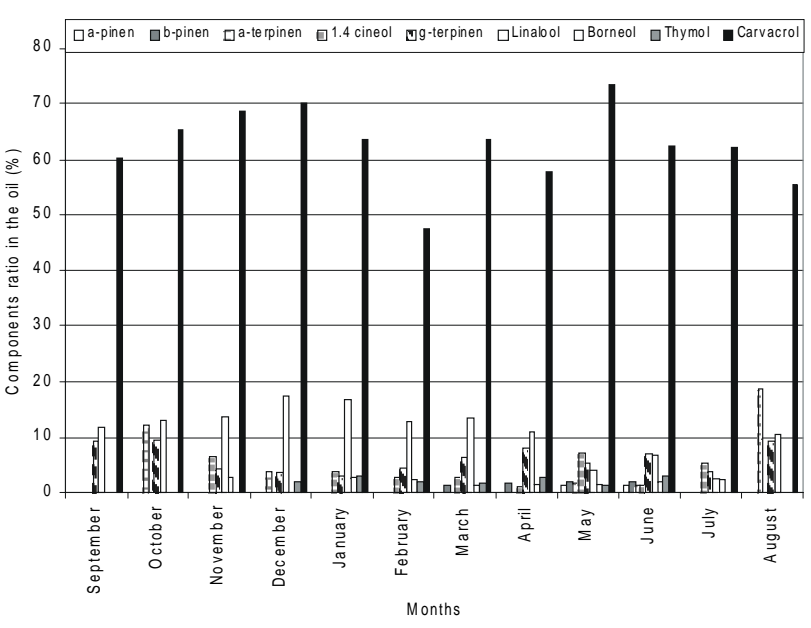

Figure 2

Variation of the essential oil components of Turkish oregano throughout the year.

Ceylan (1995) reported that the content of thymol+carvacrol in the essential oil of Origanum smyrnaeum L. reached its highest values in the flowering time. Our results are in agreement with the findings of the paper mentioned above. Similar results were also reported in the literature relating to the essential oil of Oregano (Ceylan, 1987; Kaya, 1990; Erdemgil, 1992; Ruberto et al., 1993; Vokou et al., 1998).

\section{CONCLUSON}

Turkish Oregano (Origanum onites L.) is widely collected from nature and also cultivated especially in the Aegean region of Turkey and also exported excessively abroad as a spice, essential oil or oregano water. The harvest time of oregano is very important for all kinds of usage.

As a conclusion of the present study, it could be stated that noon and afternoon harvests at post-flowering-beginning of seed formation period may result in higher values of essential oil content as well as its components. This period occurs in the second half of June in the ecological conditions of Çukurova.

\section{ACKNOWLEDGEMENTS}

This study was MSc. Thesis and supported by the Scientific Research Projects Unit of Çukurova University, Adana, Turkey.

\section{REFERENCES}

Bayram E. 1995. Geliştirilmiş Turkish Kekiği (Origanum onites L.) Hatlarinda Bazi Agronomik ve Kalite Özelliklerinin Belirlenmesi. Ege Üniversitesi Ziraat Fakültesi Dergisi, 35 (3) 41-48.

Baytop T. 1999. Türkiye'de Bitkiler ile Tedavi (Geçmiste ve Bugün). Istanbul Üniversitesi Yayinlari; No.3255-
Eczacilik Fakültesi No: 40, Sanal Matbaacilik, P: 254.

Binokay S, Özgüven M. 1987. Cukurova Kosullarinda Yetiştirilen Adi Kekik (Thymus vulgaris L.), Turkish Kekigí (Majorana hortensis Moench) ve Dağ Sateri (Satureja montana L.)'nin Drog ve Eterik Yağ Verimi Üzerinde Araştirmalar. C..Ü. Fen ve Mühendislik Bilimleri Dergisi, Cilt I, No:2, s. 53-58, Adana.

Biondi D, Ciance P, Geraci C, Ruberto G, Piattelli M. 1993. Antimicrobial activity and chemical composition of essential oils from Sicilian aromatic plants. Flavour Fragr. J. 8. 331-337.

Ceylan A. 1987. Tibbi Bitkiler-II (Uçucu Yag Içerenler) Ege Üniversitesi Ziraat Fakültesi Ofset Basimevi. Yayin No: 481: 208-220.

Ceylan A. 1995. Tibbi Bitkiler I (III. Basim) Ege Üniversitesi Ziraat Fakültesi Ofset Basimevi. Yayin No: 312, s. 116-130, Bornova-Turkish.

Davis PH. 1982. Flora of Turkey and the East Aegean Islands, Vol: 7. University Press, Edinburgh.

Demir I. 1974. Tibbi Bitkilerin Islahina Bir Bakis. Uluslar arasi Tibbi Bitkiler Kollogiumu. 18-21 Nisán 1974. Büyük Efes Oteli, Turkish, s. 29-31.

Erdemgil FZ. 1992. Origanum onites L. Ucucu Yağinin Bileșimi. Anadolu Üniversitesi Sağlik Bilimleri Enstitüsü, Yüksek lisans Tezi. Eskișehir.

Kaya N. 1990. Quality charectristics of wild Origanum onites L. from 4 regions of Turkey. Ege Üniversitesi Ziraat Fakültesi Dergisi 27 (2), 11-24.

Kokkini S. 1996. Taxonomy, diversity and distribution of Origanum species. Proceeding of the IPGRI International Workshop on Oregano. 8-12 May 1996. CIHEAM, Valenzano, Bari, Italy. Ed.: S.Padulosi. pp. 2-12.

Otan H, Sari AO, Ceylan A, Bayram E, Ozay N, Kaya N. 1994. Bati Anadolu Florasinda Yayilis Gösteren Origanum onites L. (Turkish kekiği) Populasyonlarinda Bazi Kalite Ozellikleri. Tarla Bitkileri Kongresi 25-29 Nisan 1994, Bornova, Turkish, Cilt: 1 (Agronomi Bildirileri), pp. 146-149.

Özgüven M, Stahl-Biskup E. 1989. Ecological and ontogenetical variation in essential oil of Origanum vulgare L., $37^{\text {th }}$ Annual Congress on Medicinal Plant Research, Society of Medicinal Plant Research. Braunschweig, September, pp. 5-9.

Özgüven M, Schneider M, Marquard R. 1996. Yield and quality aspect of Origanum wild species collected in the Çukurova region of Turkey. Proceedings International Šymposium Breeding Research on Medicinal and Aromatic Plants Quedlinburg - Germany, June 30 - July 4, 1996, Beiträge zur Züchtungsforschung, Bundensansalt für Züchtungsforschung an Kulturpflanzen, 2. Jahrgang., Heft 1, pp. 21-24.

Ruberto G, Biondi D, Meli R, Piattelli M. 1993. Volatile flavour components of Sicilian Origanum onites L. Flavour Fragr. J. 8, 197-200.

Tepe B, Daferera D, Sokmen M, Polissiou M, Sokmen AQ. 2004. The in vitro antioxidant and antimicrobial activities of the essential oil and various extracts of Origanum syriacum L. var bevanii. J. Sci Food Agric. 84,1389-1396.

Vokou D, Kokkini S, Bessiere J.M. 1998. Origanum onites L. (Lamiaceae) in Greece. Distrubution volatile oil yield, and composition. Economic Botany 42, 407-412. 